\title{
RESPONSIBLE RESEARCH AND INNOVATION - NEW PARADIGM OF TECHNOLOGY MANAGEMENT
}

\author{
Lukasz Nazarko \\ Faculty of Management, Bialystok University of Technology, \\ Wiejska 45A, Bialystok, Poland \\ E-mail: l.nazarko@pb.edu.pl
}

\begin{abstract}
Responsible Research and Innovation (RRI) is a cross-cutting theme for the European Union Horizon 2020 programme. On one hand it may be seen as a burden for the R\&D community but on the other, as a source of innovation and creativity aligned with the values of the society. The paper attempts to explore the possibilities of making Responsible Research and Innovation a framework that strengthens and deepens the relationship of a business with the clients and the rest of its environment. Special attention is paid to the relationship between RRI, Future-Oriented Technology Analysis and Technology Management. RRI principles are studies from the perspective of an enterprise.
\end{abstract}

Keywords: responsible research and innovation, RRI, future-oriented technology analysis, technology management, technology assessment.

JEL Classification: O32; O33; O38.

\section{Introduction}

European Union institutions and their documents are an abundant source of new terminology and jargon that penetrate various spheres of social and economic life of its member states and beyond. Recent years have witnessed the introduction of Forward-Looking Activities (FLA), FutureOriented Technology Analysis (FTA), Smart Specialisation Strategy to name just a few terms that fall within author's research interests. The common feature of all these novel phrases is their ambiguity at the moment of introduction. The terms begin to feature in the EU legal acts, programme guidelines and speeches but there remains a high degree of uncertainty as to what they actually mean.

Responsible Research and Innovation (RRI) belongs to the same category of EU-conceived terms. It first surfaced in 2009 in the context of nanotechnology development (Robinson 2009). Two years later, in May 2011, it appeared as a generic policy concept not related to any particular field of research (European Commission 2011) and it continued to spread in the EU legislation (European Parliament 2013). Since then a number EU funded projects have embarked on a quest to build common understating of RII among European stakeholders and to progress towards the operationalisation of the concept.

One of the most frequently recalled definitions that is rooted in EU policy principles and was prepared by a European Commission staff member states that Responsible Research and Innovation is a transparent, interactive process by which societal actors and innovators become mutually responsive with a view to the (ethical) acceptability, sustainability and societal desirability of the innovation process and its marketable products (in order to allow a proper embedding of scientific and technological advances in our society) (von Schomberg 2011). Another definition, a more general one, with a clearer reference to the prospective aspect of responsibility, is proposed by Stilgoe et al. (2013) and descibes RRI as taking care of the future through collective stewardship of science and innovation in the present.

This paper offers a synthesis of the current body of knowledge on Responsible Research and Innovation. It focuses on RRI relevance not only as a new framework for science, technology and innovation policy but also as a practical proposition for enterprises engaged in technological innovation. The added value of this work is the creation of conceptual link and terminological hierarchy between RRI, Future-Oriented Technology Analysis and Technology Management. The methods deployed in research presented in this paper include literature review, logical construction and bibliometrics. 


\section{Responsible Research and Innovation - a policy-relevant concept on the rise}

While RRI is a fairly young term, the problem it describes is by no means new. The complex relationship between research, technical development, innovation and dominant societal values has been discussed for a long time now. It seems, however, that - as our societies are being transformed into knowledge societies where knowledge is becoming the principal source of wealth - the debate is gaining intensity. Emergence and advances in the fields of atomic energy, biotechnology, genetic engineering, nanotechnology, brain science, human enhancement, to name just a few, are causing that RRI is coming to be increasingly prominent as a policy-relevant concept providing theoretical and practical framework for reflection and action. Figures 1 and 2 are indicative of that phenomenon.

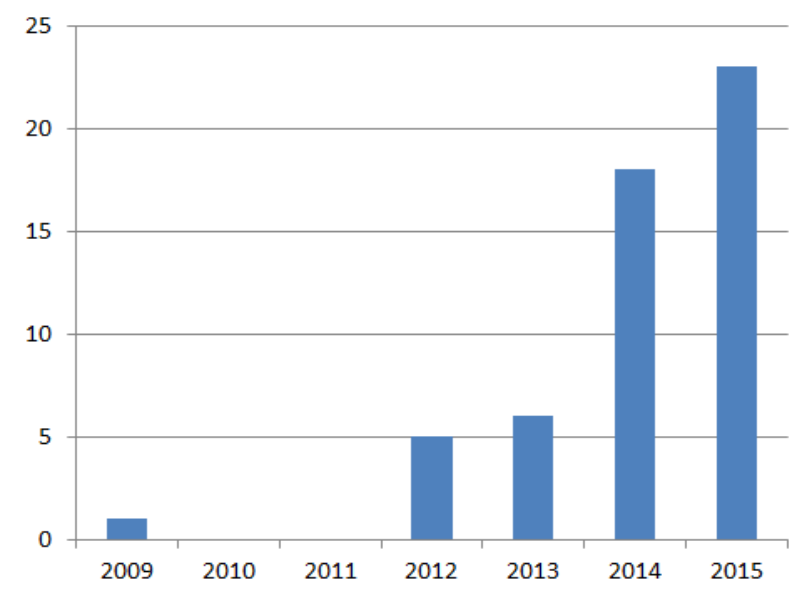

Fig. 1. Publications on the topic of "responsible research and innovation" indexed in Web of Science (Source: Thomson Reuters Web of Science)

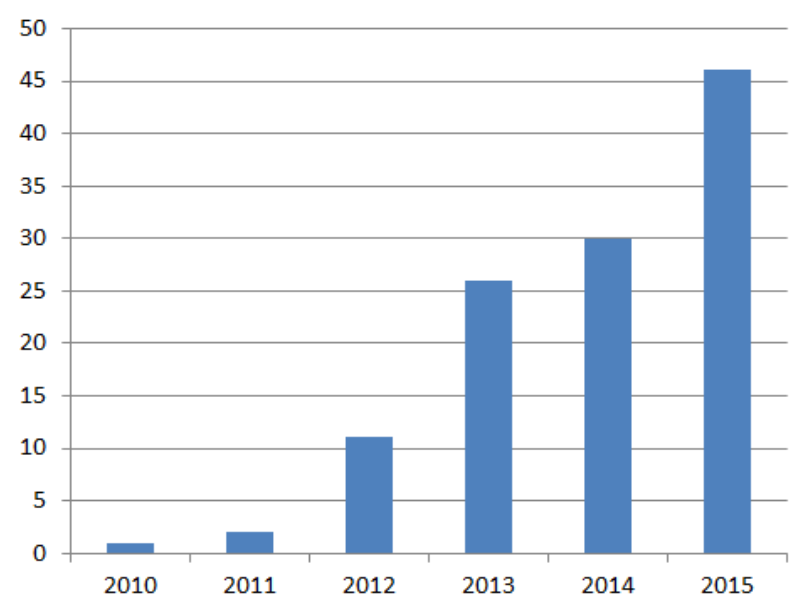

Fig. 2. Citations if works on the topic of "responsible research and innovation" indexed in Web of Science

(Source: Thomson Reuters Web of Science)
Using Thomson Reuters Web of Science as a reference one may observe that the number of publications and citations of works on the topic of Responsible Research and Innovation is consistently increasing, the work of Robinson (2009) being the earliest and the paper of Owen et al. (2012) being the most popular one on the topic. Queries concerning related topics: responsible innovation and responsible research show the same steep upward trend. In 2014 a new periodical entitled Journal of Responsible Innovation was established with the focus on exploration and application of ideas of responsibility to knowledge-based innovations and innovation policies (Guston et al. 2014).

With RRI becoming a Horizon 2020 crosscutting action one may be confident that the trend visible in the figures continues for at least half a decade from now. It will be guaranteed by the rule that $0.5 \%$ of the budgets for the "Societal Challenges" and "Industrial Leadership" pillars of H2020 would be reserved for RRI/Science with and for Society actions (European Commission 2013).

Further bibliometric analysis conducted with use of VOSviewer software (developed at the Centre for Science and Technology Studies, Leiden University) allows to distil most frequent terms that occur in the scientific literature on RRI. In Figure 3 one may observe two most prominent clusters.

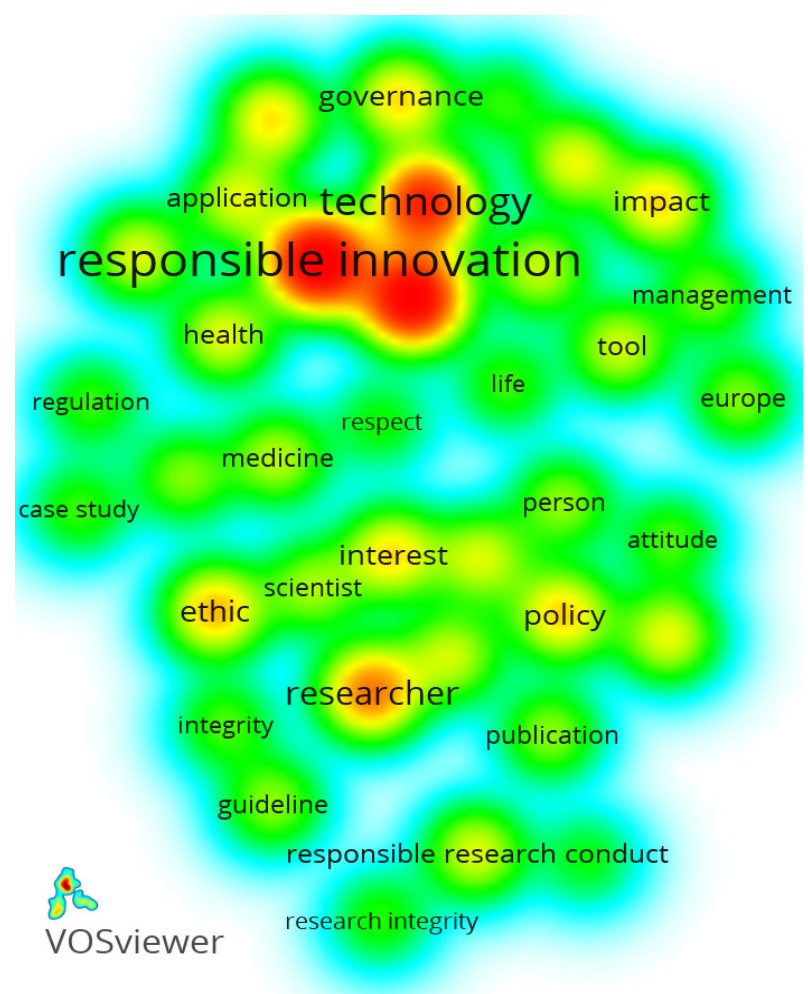

Fig. 3. Clustering and density visualisation of terms cooccurring in the scientific literature on RII

(Source: own elaboration with use of VOSviewer) 
The first cluster obtained from the analysis of titles, keywords and abstracts of 296 RRIrelated publications from years 2009-2016 indexed in Thomson Reuters Web of Science is centred around the following terms: responsible innovation, innovation, technology, impact and governance. It reflects the essence of RRI which stems from the premise that innovation and technology need governance so that their impact is understood and controlled. The second distinguishable cluster includes among others the following words: researcher, ethics, policy, interest, guideline. It stresses the role of individuals (especially researchers in the public and private sectors) in following the ethical guidelines of RRI and assuring ethical integrity of their endeavours in the innovation domain. Although not at the top of the list, Europe is the only geographical term that features prominently in the scholarly works on the subject. This observation is in line with the origin of RRI as a concept and with the fact of its adoption as an EU policy.

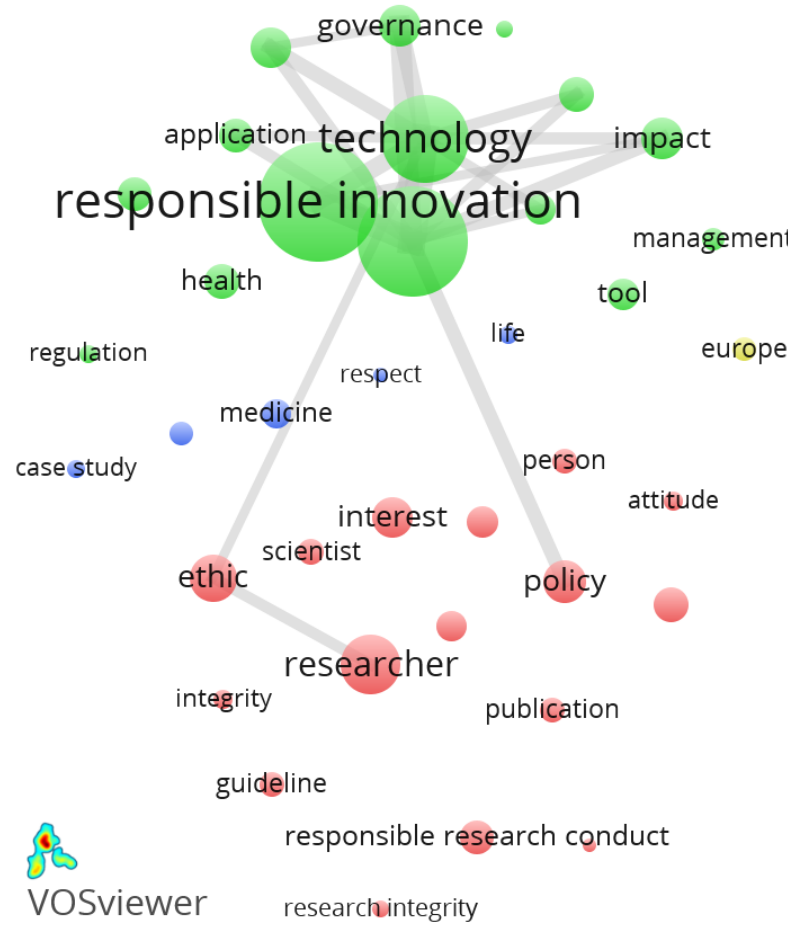

Fig. 4. Bibliometric network displaying terms occurring in the scientific literature on RII as well as their co-occurrence (Source: own elaboration with use of VOSviewer)

The conclusions from the clustering exercise presented above are reinforced by the information on the bibliometric networks visible in Figure 4. The strongest links (between 10 and 30 occurrences) exist between the following terms: innovation, responsible innovation, technology, policy, impact, governance, future, application, ethics. Additionally, sectoral foci of RRI are revealed by frequent occurrence and strong interconnection of nanotechnology, medicine and health. This points to the science and technology domains that evoke most questions and dilemmas of social, environmental and ethical nature (Nazarko et al. 2013a) and suggests that more in-depth RII-related technology mapping is required (Gudanowska 2014).

\section{Reflections on responsibility in the context of research and innovation}

Out of the three nouns constituting the discussed term responsible is definitely the most ambiguous one (research and innovation having been thoroughly discussed and generally understood in the academic and policy-maker communities). Despite that lack of clarity one may say that this is the word responsible that makes RRI such a trendy, incontestable intuitively right concept (Owen et al. 2013). In the end, who would prefer "irresponsible" research and innovation instead of "responsible" research and innovation?

There are different dimensions of and different lenses though which one may look at responsilbity. Grunwald (2016) proposes three constitutive dimensions of responsibility: empirical, ethical and epistemological (Fig. 5).

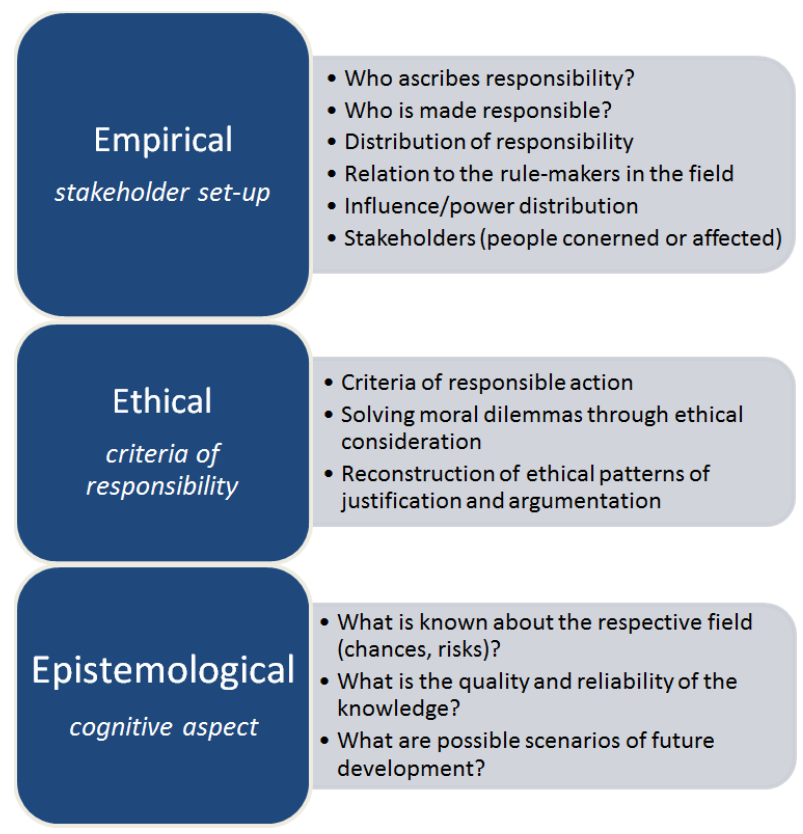

Fig. 5. Dimensions of responsibility in the context of Responsible Research and Innovation (Source: own elaboration based on Grunwald 2016) 
In order to help organisations comprehend the concept of responsibility in research and innovation and find their role to play Grunwald (2013) proposes a five-stage reconstruction (Fig. 6).

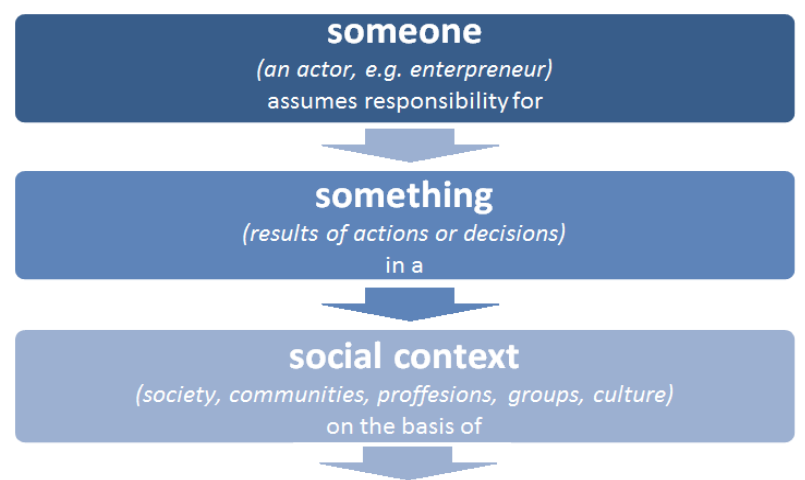

\section{body of rules and criteria}

(normative framework valid in respective situation) relative to the

\section{status of available knowledge}

(about the consequences of the actions, scenarios, speculative concerns, expectations )

Fig. 6. Five-stage reconstruction of the concept of responsibility in the context of Responsible Research and Innovation (Source: own elaboration based on Grunwald 2013)

Going further down to the practical level and expanding the concept of Iatridis and Schroeder (2016) one may conclude that an organisation (enterprise, R\&D unit, NGO etc.) finds itself in the relation of responsibility with the following actors: owners (supervisors or shareholders), government, consumers, business partners, employees, natural environment and wider society (Fig. 7).

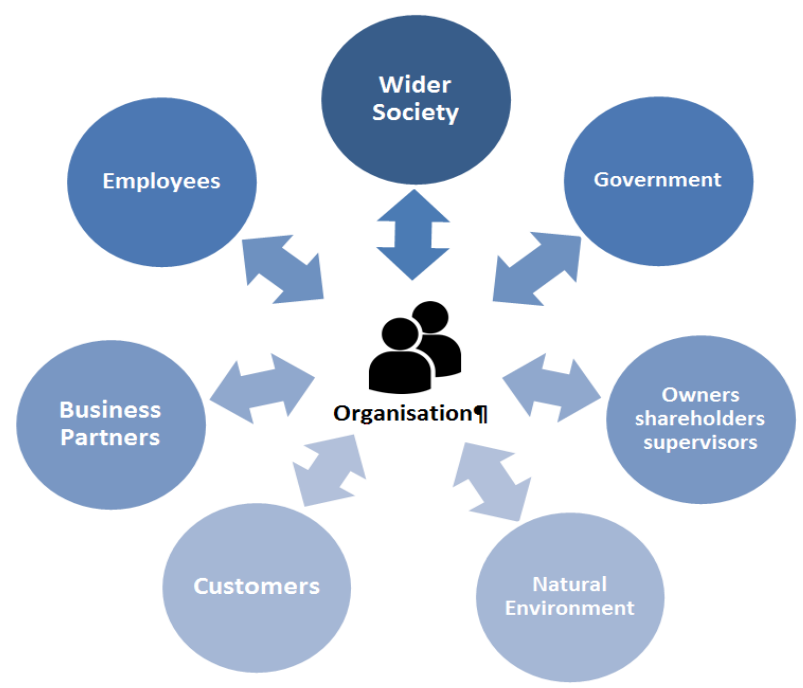

Fig. 7. Relations of responsibility in the RRI context (Source: own elaboration)
It should be stressed that the relation of responsibility is usually mutual (although not necessarily based on reciprocity principle). It may be generally categorised into three types (Iatridis, Schroeder 2016):

- Contractual responsibility - stemming from the contracts effected between two or more parties (high specificity).

- Legal responsibility - stemming from the fact of operating in a particular business field in a given national and international legal environment (medium specificity).

- Moral responsibility - stemming from the values represented by the organisation and/or by the wider society (low specificity).

Current socio-economic context demands of the enterprises to look at the notion of (corporate) responsibility not only form the perspective of burden, constraints and arising costs but also as relationships that create opportunities to align their innovation systems to the needs and values of the society. Thus, internalising the concept of responsibility in the culture and strategy of a company may facilitate in the longer term the development of new products and services that are competitive in the market thanks to the deeper and more sophisticated understanding of customers' needs and aspirations. RRI may be treated as a lens through which all aspects of corporate responsibility related to the process, procedures and outcomes of innovation processes are visible (Fig. 8).

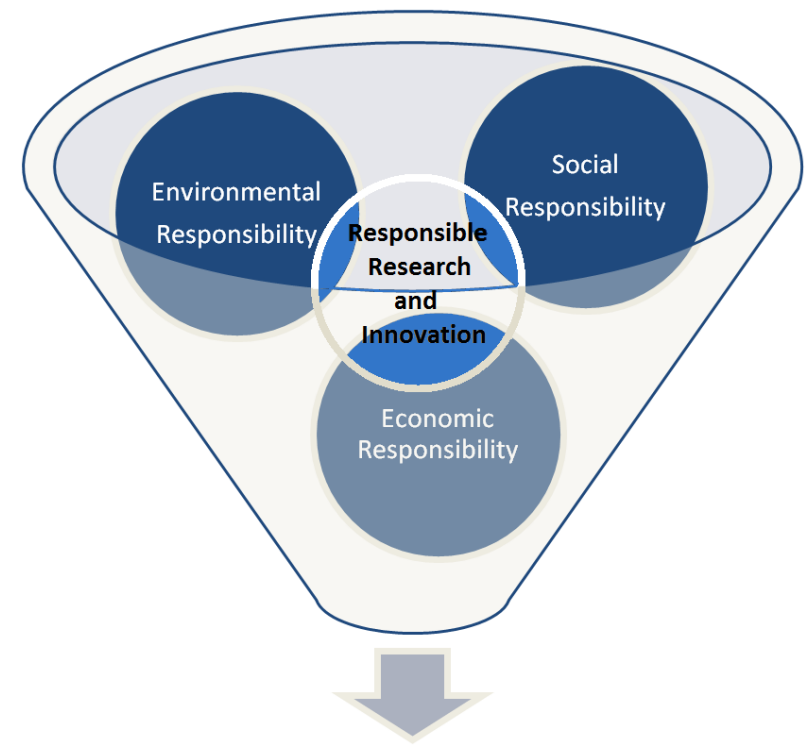

\section{CORPORATE RESPONSIBILITY}

Fig. 8. Relation of RRI to Corporate Responsibility and its elements (Source: own elaboration based on Iatridis, Schroeder 2016) 
The concept of Responsible Research and Innovation assumes that there is more to the responsibility of an enterprise than just to use its resources and engage in activities designed to increase its profits so long as it remains engaged in open and free competition, without deception or fraud (Friedman 1962). RRI expects that enterprises show active commitment to effecting a change for better in the community, society and country (Drucker 1993) and that they show the ability to answer for their impacts (European Commission 2011). As one can see, there is a clear shift in the centre of gravity - from the shareholder to the stakeholder.

\section{Relation of RRI to other concepts}

One may list a number of terms and concepts that deal with the interplay between scientific/technological progress and its social, economic, environmental, political and spiritual impacts. An ad-hoc (and surely incomplete) list includes: responsible development; research integrity; responsilbe research conduct; constructive technology assessment; real-time technology assessment; anticipatory governance; public engagement in science; creating shared value; ethical, legal and social implications of science (ELSI); ethical, legal and social aspects of science (ELSA), value-sensitive design, corporate social responsibility; corporate responsibility; corporate sustainability; corporate accountability; corporate citizenship; corporate social performance; responsible innovation; responsible industry and innovation systems; responsive stewardship; sustainable and social innovation; midstream modulation; upstream engagement; environmental and social impact assessment (Ejdys 2004); life cycle (sustainability assessment); strategic environmental assessment (Nazarko 2015a).

The very realisation of the number of various terms and concepts connected to responsibility and social awareness in R\&I activity is quite overwhelming. It opens an opportunity for researches to catalogue, characterise and develop typologies of the aforementioned approaches. That would bring about some much needed clarity and intellectual tidiness to the RRI discourse.

Whereas it is beyond author's capabilities to work out in this paper a coherent classification of all the concepts listed in the previous paragraphs, a proposition to link some key RRI-related frameworks is offered here (Figs 9-11).

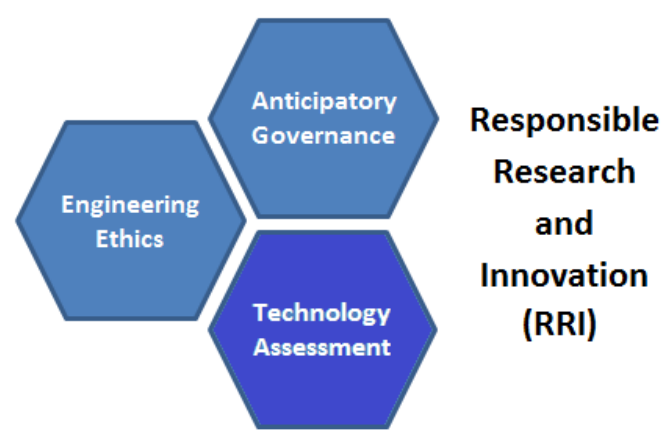

Fig. 9. Conceptual structure of Responsible Research and Innovation (Source: own elaboration based on Grunwald 2011)

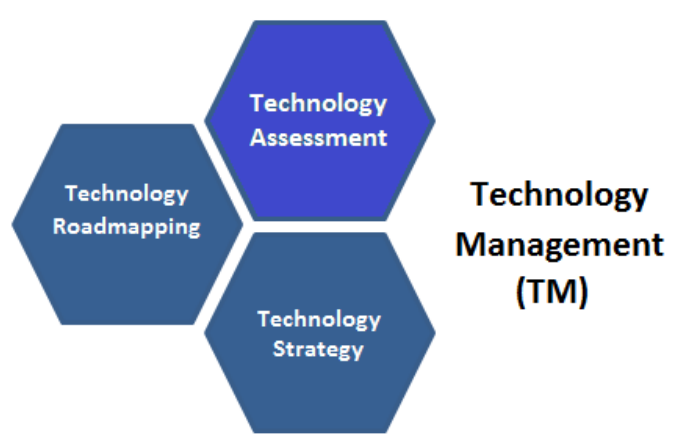

Fig. 10. Conceptual structure of Technology Management (Source: own elaboration based on Magruk 2011)

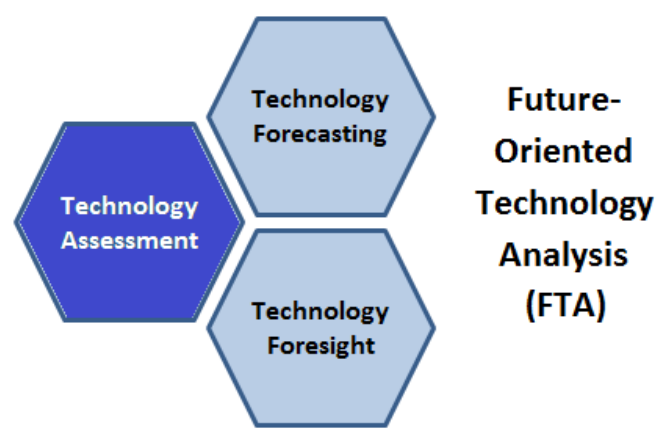

Fig. 11. Conceptual structure of Future-Oriented Technology Analysis (Source: own elaboration based on Nazarko et al. 2013b; Ejdys, Nazarko 2014; Halicka et al. 2015; Nazarko 2015a)

It was noticed that all three key concepts concerning scientific/technological progress and its impacts on Earth and humanity (i.e. Responsible Research and Innovation, Technology Management and Future-Oriented Technology Analysis) make references to Technology Assessment (TA). TA may be defined as the systematic study of the effects on society, that may occur when a technology is introduced, extended, or modified with emphasis on the impacts that are unintended, indirect, or delayed (Coates 1976).

In Figure 12 author puts forward Technology Assessment an "anchor concept" that connects RRI, FTA and TM. 


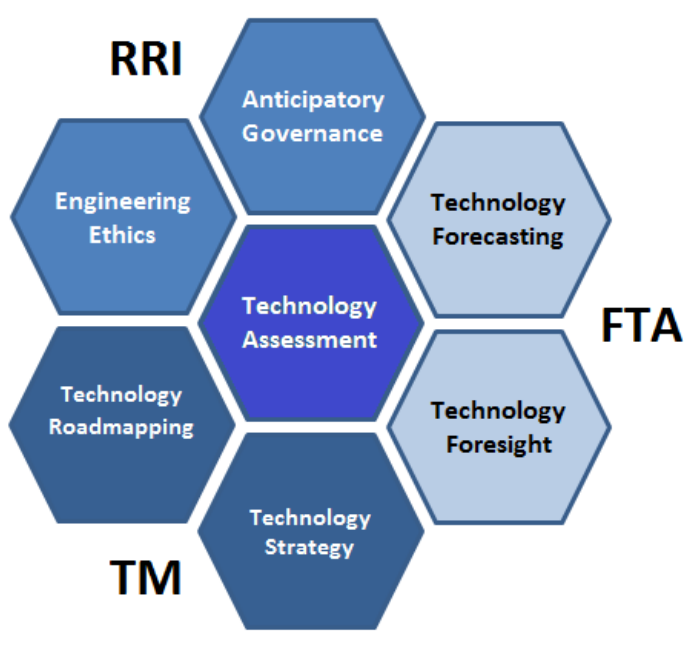

Fig. 12. Integration of RRI, FTA and TM with TA as an anchor concept (Source: own elaboration)

Figure 12 reveals that TA, which is a wellgrounded idea developed since the 70 s, may serve as reference point for elaborating and refining younger concepts of RRI and FTA. The figure also shows that - thanks to its connection to Technology Management - TA may be seen as an effective channel of making Responsible Research and Innovation relevant to the business world. And conversely, the growing popularity of RRI may induce interest in TA as a promising management instrument suitable for a complx and fast-changing business environment (Belina et al. 2015; Ejdys et al. 2014).

\section{Relevance of RRI for technology management in enterprises}

RRI was initially promoted as a research and innovation governance framework especially suited for public funders of research and decision-makers in the innovation policy domain (Nazarko 2011). The framework encompassed six policy agendas: Governance, Science Education, Ethics, Open Access, Gender Equality and Public Engagement. Scholars, practitioners and policy-makers soon realised the potential the RRI has in the business environment (Griessler 2015; Iatridis, Schroeder 2016). Table 1 presents the RRI policy agendas accompanied by explanation in what way each agenda is relevant and applicable in business and industry.

Basing on the work of Guadamillas-Gomez and Donate-Manzanares (2011), Iatridis and Schroeder (2016) make effort to pair up RRI principles and agendas with concrete Corporate Responsibility tools to show the strong interdependence between the two frameworks. Additionally, they provide a list of ready-to-undertake practices
Table 1. RRI principles and their applicability in business and industry. (Source: own elaboration based on Nazarko et al. 2012; Owen et al. 2013; von Schomberg 2013; Iatridis, Schroeder 2016; RRI Tools 2016)

\begin{tabular}{|c|c|}
\hline $\begin{array}{l}\text { RRI } \\
\text { principle }\end{array}$ & $\begin{array}{l}\text { Relevance and applicability } \\
\text { in businenss and industry }\end{array}$ \\
\hline Ethics & $\begin{array}{l}\text { Ethical considerations to be embedded } \\
\text { in the R\&I process from the beginning. }\end{array}$ \\
\hline $\begin{array}{l}\text { Gender } \\
\text { equality }\end{array}$ & $\begin{array}{l}\text { Affects industries' traditional struc- } \\
\text { tures, offering new business opportu- } \\
\text { nities, enhancing creative potential. }\end{array}$ \\
\hline Governance & $\begin{array}{l}\text { RRI as an extended version of Corpo- } \\
\text { rate Social Responsibility (CSR). }\end{array}$ \\
\hline $\begin{array}{l}\text { Open } \\
\text { Access }\end{array}$ & $\begin{array}{l}\text { A way to foster Open Innovation } \\
\text { in enterprises. }\end{array}$ \\
\hline $\begin{array}{l}\text { Public } \\
\text { Engagement }\end{array}$ & $\begin{array}{l}\text { Engaging stakeholders in the imple- } \\
\text { mentation of socially desirable re- } \\
\text { sponsibility measures in end-products } \\
\text { and industrial processes. }\end{array}$ \\
\hline $\begin{array}{l}\text { Science } \\
\text { Education }\end{array}$ & $\begin{array}{l}\text { Increasing work force innovation } \\
\text { capability thanks to innovation and } \\
\text { science education strategies. }\end{array}$ \\
\hline Sustainability & $\begin{array}{l}\text { Identification of the environmental } \\
\text { aspects of business operations. Smart } \\
\text { use of natural resources and investment } \\
\text { in eco-efficient production processes. }\end{array}$ \\
\hline $\begin{array}{l}\text { Risk } \\
\text { Management }\end{array}$ & $\begin{array}{l}\text { Moving beyond limited view of risk } \\
\text { to encompass often fuzzy risks arising } \\
\text { from R\&I activities. }\end{array}$ \\
\hline $\begin{array}{l}\text { Human } \\
\text { Wellbeing }\end{array}$ & $\begin{array}{l}\text { Care for health and safety } \\
\text { in the workplace; observing human } \\
\text { rights and labour rights of employees. }\end{array}$ \\
\hline Anticipation & $\begin{array}{l}\text { Refining the organisational "future- } \\
\text { proofing" with TA and foresight } \\
\text { so that it is easier to anticipate possi- } \\
\text { ble future outcomes of research } \\
\text { and innovation and their intended } \\
\text { and non-intended consequences. }\end{array}$ \\
\hline Reflexivity & $\begin{array}{l}\text { Reflecting on underlying motivations, } \\
\text { potential impacts, uncertainties, risks, } \\
\text { areas of ignorance, assumptions, ques- } \\
\text { tions, and dilemmas. Building "reflex- } \\
\text { ive capital" by analysing the purposes, } \\
\text { processes, and products of science } \\
\text { and innovation in an iterative, inclu- } \\
\text { sive, and deliberative way. }\end{array}$ \\
\hline $\begin{array}{l}\text { Deliberation } \\
\text { (Inclusion) }\end{array}$ & $\begin{array}{l}\text { Processes of engagement and dialogue } \\
\text { with different stakeholders. This ena- } \\
\text { bles the introduction of a wide range } \\
\text { of perspectives to reframe issues } \\
\text { and the early warning for areas of po- } \\
\text { tential conflict. }\end{array}$ \\
\hline $\begin{array}{l}\text { Responsive- } \\
\text { ness }\end{array}$ & $\begin{array}{l}\text { An iterative process of adaptive learn- } \\
\text { ing that should be driven by the com- } \\
\text { pany ethos. Ensuring responsiveness } \\
\text { to stakeholders in the spirit of RRI. }\end{array}$ \\
\hline
\end{tabular}


that enable implementation of RRI. That list includes internal and external auditing procedures; interaction with customers; surveys conducted to enhance supply chain management; information transparency, accountability and best practice approaches; dissemination of results on corporate social, environmental and financial performance; obtaining environmental and quality certification; promotion of learning and professional development.

\section{Conclusions}

RRI is a new conceptual proposition in the domain of innovation governance and technology management. As it normally happens, the development of a concept should be followed by elaborations on the operational level. Therefore the author considers the study on RRI tools and metrics a very promising and uncharted research direction.

With RRI becoming a Horizon 2020 crosscutting action (European Commission 2013) one may be confident that the trend visible in the Figures 1 and 2 continues for at least half a decade from now. It remains to be seen, however, if later on RRI establishes itself for good as a robust framework of innovation-society relations or if it gives way to some next fashionable concepts that would evoke a new wave excitement among the EU policy makers.

Despite a certain degree of uncertainty regarding the future of the RRI concept it was argued in the paper that Responsible Research and Innovation, unlike smart specialisation (Nazarko 2014), has a potential to grow into a well founded framework for evaluating the role of science and technology in contemporary society. This article has established a conceptual link between RRI, Technology Management and Future-Oriented Technology Analysis with Technology Assessment as an anchor. It is author's hope that this work serves as a useful entry point for other studies in the field of RRI.

\section{References}

Belina, B.; Mazurkiewicz, A.; Giesko, T.; Karsznia, W. 2015. Tracking and predicting solution development in R\&D projects using a complex assessment method, Economics and Management 7(3): 7-14. http://dx.doi.org/10.12846/j.em.2015.03.01

Coates, J. F. 1976. Technology assessment - a tool kit, Chemtech 6: 372-383.

Drucker, P. F. 1993. Post-capitalist society. Oxford: Butterworth-Heinemann.
Ejdys, J. 2004. Metoda oceny wyników działalności środowiskowej. Bialystok: Oficyna Wydawnicza Politechniki Białostockiej.

Ejdys, J.; Ginevicius, R.; Halicka, K.; Ustinovicius, L. 2014. Interdyscyplinarnosc i niestandardowe zastosowania wybranych nowoczesnych metod zarzadzania w gospodarce w dorobku naukowym Profesora Joanicjusza Nazarko, Economics and Management 6(4): 7-27. http://dx.doi.org/10.12846/j.em.2014.04.01

Ejdys, J.; Nazarko, Ł. 2014. Foresight gospodarczy instrumentem orientacji na przyszłość, Prace Naukowe Uniwersytetu Ekonomicznego we Wrocławiu 340: 651-664.

http://dx.doi.org/10.15611/pn.2014.340.58

European Commission. 2011. DG research workshop on responsible research \& innovation in Europe, 16-17 May 2011, Brussels, Belgium [online], [cited 04 June 2016]. Available from Internet: http://ec.europa.eu/research/sciencesociety/document_library/pdf_06/responsibleresearch-and-innovation-workshopnewsletter_en.pdf

European Commission. 2013. Fact sheet: science with and for society in Horizon 2020 [online], [cited 04 June 2016]. Available from Internet:

https://ec.europa.eu/programmes/horizon2020/sites /horizon2020/files/FactSheet_Science_with_and_f or_Society.pdf

European Parliament. 2013. Regulation (EU) No 1291/2013 of the European Parliament and of the Council of 11 December 2013 establishing Horizon 2020 - the framework programme for research and innovation (2014-2020) and repealing Decision No 1982/2006/EC.

Friedman, M. 1962. Capitalism and freedom. Chicago: University of Chicago Press.

Griessler, E. 2015. Measuring the immeasurable: some empirical observations across Europe on private companies' use of RRI, in Conference "RRI Shaping new Horizons: Responsible Research and Innovation in Europe and across the World", 14-15 January 2016, Brussels, Belgium [online], [cited 04 June 2016]. Available from Internet:

http://www.eesc.europa.eu/resources/docs/3-erichgriessler.pdf

Grunwald, A. 2011. Responsible innovation: bringing together technology assessment, applied ethics, and sts research, Enterprise and Work Innovation Studies 7: 9-31 [online], [cited 04 June 2016]. Available from Internet: www.itas.kit.edu/pub/v/2011/grun11c.pdf

Grunwald, A. 2013. The EEE concept of responsibility ethical, empirical and epistemological constituents. Paris [online], [cited 04 June 2016]. Available from Internet: http://www.great-project.eu/files/armin-grunwald

Grunwald, A. 2016. Parliamentary technology assessment as an institutional realisation of RRI, in con- 
ference "RRI Shaping new Horizons: Responsible Research and Innovation in Europe and across the World', 14-15 January 2016, Brussels, Belgium [online], [cited 04 June 2016]. Available from Internet: http://www.eesc.europa.eu/ resources/docs/armin-grunwald.pdf

Guadamillas-Gomez, F.; Donate-Manzanares, M. J. 2011. Ethics and corporate social responsibility integrated into knowledge management and innovation technology, The Journal of Management Development 30(6): 569-581.

http://dx.doi.org/10.1108/02621711111135170

Gudanowska, A. E. 2014. Mapowanie technologii jako jedna $\mathrm{z}$ metod analizy technologii $\mathrm{W}$ świetle wybranych zagranicznych doświadczeń, Economics and Management 6(1): 265-281. http://dx.doi.org/10.12846/j.em.2014.01.16

Guston, D. H.; Fisher, E.; Grunwald, A.; Owen, R.; Tsjalling, S.; van der Burg, S. 2014. Responsible innovation: motivations for a new journal, Journal of Responsible Innovation 1(1): 1-8. http://dx.doi.org/10.1080/23299460.2014.885175

Halicka, K.; Lombardi, P.A.; Styczynski, Z. 2015. Future-oriented analysis of battery technologies in IEEE International Conference on Industrial Technology (ICIT), 17-19 March 2015, Seville, Spain. http://dx.doi.org/10.1109/icit.2015.7125231

Iatridis, K.; Schroeder, D. 2016. Responsible research and innovation in industry. The case for corporate responsibility tools. Springer. http://dx.doi.org/10.1007/978-3-319-21693-5

Magruk, A. 2011. Foresight technologiczny a zarządzanie technologia, Problemy Eksploatacji 3(2011): 47-60.

Nazarko, J. 2011. Kształtowanie polityki proinnowacyjnej regionu np. foresightu technologicznego "NT FOR Podlaskie 2020", Optimum. Studia Ekonomiczne 50(2): 241-251.

Nazarko, J.; Ejdys, J.; Debkowska, K. 2012. Model oraz wyniki pilotażowego badania typu foresight w obszarach wzrost gospodarczy, innowacyjność mazowieckich przedsiębiorstw, rozwój lokalny. Politechnika Białostocka, Białystok.

Nazarko, J.; Ejdys, J.; Halicka, K.; Olszewska, A.; Gudanowska A.; Krawczyk-Dembicka, E.; Nazarko, L. 2013a. Nanonauka na rzecz rozwoju województwa podlaskiego. Bialystok: Oficyna Wydawnicza Politechniki Białostockiej.

Nazarko, J.; Glinska, U.; Kononiuk, A.; Nazarko, L. 2013b. Sectoral foresight in Poland: thematic and methodological analysis, International Journal of Foresight and Innovation Policy 9(1): 19-38. http://dx.doi.org/10.1504/IJFIP.2013.051759

Nazarko, L. 2014. Inteligentne specjalizacje polskich regionów - przyczynek do ewaluacji, Przedsiębiorczość i Zarzqdzanie 15(8/1): 247-262.

Nazarko, L. 2015a. Technology assessment in construction sector as a strategy towards sustainability, Procedia Engineering 122: 290-295. http://dx.doi.org/10.1016/j.proeng.2015.10.038

Nazarko, L. 2015b. Polityka innowacyjna - inteligentny interwencjonizm? Optimum. Studia ekonomiczne 73(1): 85-96.

Owen, R.; Macnaghten, P.; Stilgoe, J. 2012. Responsible research and innovation: from science in society to science for society, with society, Science and Public Policy 39(6): 751-760. http://dx.doi.org/10.1093/scipol/scs093

Owen, R.; Stilgoe, J.; Macnaghten, P.; Gorman, M.; Fisher, E.; Guston, D. 2013. A framework for responsible innovation, in R. Owen, J. Bessant, M. Heintz. Responsible innovation. John Wiley \& Sons. http://dx.doi.org/10.1002/9781118551424.ch2

RRI Tools. 2016. Decription of the project [online], [cited 04 June 2016]. Available from Internet: http://www.rri-tools.eu/faq

Robinson, D. K. R. 2009. Co-evolutionary scenarios: an application to prospecting futures of the responsible development of nanotechnology, Technological Forecasting and Social Change 76(9): 1222-1239. http://dx.doi.org/10.1016/j.techfore.2009.07.015

Stilgoe, J.; Owen, R.; Macnaghten, P. 2013. Developing a framework for responsible innovation, Research Policy 42(9): 1568-1580.

http://dx.doi.org/10.1016/j.respol.2013.05.008

von Schomberg, R. 2011. Prospects for technology assessment in a framework of responsible research and innovation, in M. Dusseldorp, R. Beecroft (Eds.). Technikfolgen Abschätzen Lehren: Bildungspotenziale Transdisziplinärer Methode. Wiesbaden: Springer. http://dx.doi.org/10.1007/978-3-531-93468-6_2

von Schomberg, R. 2013. A vision of responsible research and innovation, in R. Owen, J. Bessant, M. Heintz (Eds.). Responsible innovation: managing the responsible emergence of science and innovation in society. London: John Wiley. http://dx.doi.org/10.1002/9781118551424.ch3 